\title{
Local Product Marketing Strategy (Home Industry) in ASEAN Economic Community (AEC) Era
}

\author{
Nur Handayani ${ }^{1} \&$ Lilis Ardini ${ }^{1}$ \\ ${ }^{1}$ Accounting Department, Sekolah Tinggi Ilmu Ekonomi Indonesia (STIESIA) Surabaya, Indonesia \\ Correspondence: Nur Handayani, Accounting Department, Sekolah Tinggi Ilmu Ekonomi Indonesia (STIESIA) \\ Surabaya, Indonesia.
}

Received: December 6, 2017

Accepted: December 28, $2017 \quad$ Online Published: January 11, 2018

doi:10.5430/ijba.v9n1p75

URL: https://doi.org/10.5430/ijba.v9n1p75

\begin{abstract}
The ASEAN free market era (ASEAN Economic Community) encourages countries that are members of ASEAN organizations to compete globally, including Indonesia. This research is a qualitative research with focus group discussion method (FGD). The subject of this research is home industries that joined in Self Help Group (SHGs) group of 19 groups. These SHGs are chosen because they have high entrepreneurship power. Entrepreneurship is needed as a fundamental force of SHG in order to create a sustainable and growing business. The result of focus group discussion is the formation of the same perception and goals in making the home industry business is survive and sustainable through several strategies. Some of the strategies adopted based on FGD results are marketing strategy through exhibition both national and international. This strategy is expected to introduce local products from home industry in the eyes of the world to face MEA competition. This will increase local wisdom value in the era of ASEAN Economic Community (AEC).
\end{abstract}

Keywords: AEC, local product, home industry, marketing

\section{Introduction}

Indonesia, have abundant of women entrepreneurs that visible contribution to the national economy. Women entrepreneurship is the process where women play a role in business and provides employment opportunities, it can be engaged in both organized and unorganized sectors (Das et al, 2015). Micro, Small and Medium Enterprises (MSMEs) have an important and strategic role in national economic development. In addition to its role in economic growth and employment, MSMEs also play a role in distributing development outcomes. MSMEs have also been shown to be unaffected by the crisis. When the crisis hit the period of 1997 - 1998, only MSMEs were able to remain strong. Data from the Central Bureau of Statistics shows that after the economic crisis of 1997-1998 the number of MSMEs has not decreased, it has been increasing, even absorbing 85 million to 107 million workers until 2012. In that year, the number of entrepreneurs in Indonesia is 56,539,560 units. Of this amount, Micro Small and Medium Enterprises (MSMEs) of 56,534,592 units or $99.99 \%$. The rest, about $0.01 \%$ or 4,968 units is a big business (Bank of Indonesia, 2015). The data proves, MSMEs able to increase economic growth and improve the welfare of people, especially in the economic field. These sectors are expected to offer opportunities to different cross sectional people of the society to get involved into income generating activities-traditional, technological, vocational and other activities and thereby strengthening the efforts towards achieving high and sustainable economic growth which are most important prerequisites for triggering an exit from vicious poverty circle (Jahur \& Quadir, 2012).

The current Indonesian economy is formed through a process of transformation from an agriculture-based economy to an industrial economy in decades. The process of accelerating the Indonesian economy is formed through the creation of sectors of business activity at various levels ranging from the lowest level of business activities called SMEs to large industries (Indiarti \& Anton, 2014). MSMEs growth is bigger than big business. But today UMKM faces several problems one of which is trade liberation (Setyanto et al, 2015). One of the gates of trade liberation is the enactment of ASEAN Economic Community. In accordance with the main pillar initiated in the ASEAN Economic Community (MEA) in 2015, will create a single market in the ASEAN region. This single market will bring about a free flow of trade in goods, services, capital and investment (Nuraini, et al., 2016). According to research by Meliala et al (2014) out of a total of 30 SMEs studied only $10 \%$ are ready to face ASEAN free trade. While the rest feel pessimistic to be able to survive facing free trade. SMEs who are not ready to face free trade has a 
chance to not survive. Therefore, in an effort to strengthen MSMEs as national economic fundamentals, it is necessary to create a conducive domestic investment climate in order to strengthen the domestic market so that SMEs can become the buffer of the national economy.

One form of SMEs in the city of Surabaya is home industry incorporated in SHGs. The study of Handayani \& Ardini (2016) resulted in this grouping of SHG into three categories: strong, moderate, and low entrepreneurship. Of the total 75 SHGs in the city of Surabaya, there are 19 groups with strong entrepreneurship ability (25.33\%). This can be used as initial capital in establishing SHG's readiness to face liberal trade in the form of ASEAN Economic Community (AEC). From the background of the research, this research will focus on SHG empowerment to find strategies in order to introduce local product in national and international area in order to face free trade of AEC or provide estimates in answer to the question.

\section{Literature Review}

Self-Help Group is a group of people who voluntarily unite in groups because they help each other and work together to build financial service sources to encourage and develop productive enterprises and improve the standard of living of members and their families. In addition KSM has a unifying ties, namely the existence of vision, interests and needs the same, so that the group has a common goal to be achieved together. KSM in the city of Surabaya is formed in every urban village of Surabaya with the guidance of BAPEMAS and KB city of Surabaya. SHGs were given skills training in groups and developed their business in groups.

Research activities in this second year cannot be separated from cultivating the entrepreneurial spirit in KSM, meaning to be entrepreneur (entrepreneur) is of course the basic rights of all people. Not because we have no business entrepreneurs so as to close the opportunity to become entrepreneurs. The first step that we do when interested to plunge into the world of entrepreneurship is to grow the entrepreneurial spirit in us. Many ways can be done for example (1). Through formal education. Now various institutions of both middle and high education present various programs or at least entrepreneurship courses, (2). Through entrepreneurial seminars. Various entrepreneurial seminars are often organized by inviting entrepreneurial experts and practitioners so that through this medium we will build entrepreneurial spirit in ourselves, through training. Various business simulations are usually provided through training both indoor (indoor) and outdoor (3). Through this training, our courage and responsiveness to the dynamics of change in the environment will be tested and always improved and developed by autodidact, (4). Through various media we can cultivate the spirit of entrepreneurship. For example through the biography of successful entrepreneurs (success story), television media, radio newspaper magazines and various media that we can access to grow the entrepreneurial spirit that exists in us (Suryana, 2003).

Understanding interest in entrepreneurship is the interest of someone to conduct independent business activities with the courage to take risks. High interest means the awareness that the entrepreneur is attached to him so that the individual is more attentive and loves to engage in entrepreneurial activity. According to Susatyo in Sukardi (2008), entrepreneurs have six characteristics, namely self confidence, originality, people oriented, task result oriented, future oriented, and risk taking. Littunen (2000) mentions two characteristics of self-employed, namely the creativity and courage in taking risks. While Marbun (in Alma, 2000) mentions seven characteristics, namely self-confidence, task-oriented and outcome, risk-taking, leadership skills, ideality of ideas, clear vision of the future, and creativity in the execution of tasks. According Siswoyo (2009) that the development of entrepreneurial spirit has become an important thing in the future. Entrepreneurship has become an important role. Through entrepreneurship will create employment opportunities for the community. This is mainly for developing people. This article will explain developing entrepreneurship for students and lecturers. They have a strategic role position in developing entrepreneurial attitudes. Entrepreneurship program mainly in the practice of entrepreneurship, on entrepreneurship of job training; looking for business opportunities through lecturer's activities; using industrial cooperation agreement. According Mutaqin (2010) that the independence of a person is very necessary in the framework of facing the era of competition is so tight in getting jobs. One effort that can be done among others is to provide briefing in the form of activities or training on entrepreneurship. This entrepreneurial activity in order to improve the spirit of entrepreneurship, Entrepreneurship education developed is tailored to the technology and vocational education, namely technology entrepreneurship education. The concept of entrepreneurship technology education inculcates and encourages students from an early age to constantly think and develop creative ideas, designing, creating and developing business.

\subsection{Characteristics of Entrepreneurship}

According to Izedonmi \& Okafor (2007), individuals with an entrepreneurial characteristic have the ability to identify opportunities and drive resources to achieve their goals. Entrepreneurial characteristics are identified as 
central to the behavior and performance of an entrepreneur. Characteristics owned by an entrepreneur, as follows 1) Needs (motivation) achievement; 2) focus control; 3) Risk Taking; 3) Proactive; 4) Tolerance to uncertainty; 5) Creativity.

Peggy A Lambing \& Charles R. Kuehl (in Hendro \& Chandra, 2006) states that every successful entrepreneur has four main elements: ability (relation to IQ and skill), courage (relation to Emotional Quotient and mental) Determination (relation to self-motivation), creativity that requires an inspiration as the forerunner of ideas to find opportunities based on intuition (relation to experience).

\subsection{Criteria for Micro Small and Medium Enterprises (MSMEs)}

Criteria for business implementation included in Micro, Small and Medium Enterprises have been regulated in a law of law. Based on Law Number 20 of 2008 on Micro, Small and Medium Enterprises (MSMEs) there are several definitions and criteria for Micro, Small and Medium Enterprises. Criteria of Micro, Small and Medium Enterprises (MSMEs) according to Law Number 20 of 2008. UMKM has the following criteria first micro enterprises, ie productive businesses owned by individuals or business entities owned by individuals that meet the following criteria a) having a net worth of at most Rp50.000.000 (fifty million rupiah) excludes land and building of business premises; b) has annual sales of at most Rp3.000.000.000 (three hundred million rupiah). Second, small-scale business, which is a stand-alone productive economic enterprise undertaken by an individual or a business entity which is not a subsidiary or non-owned subsidiary, is controlled or becomes a part of the direct or indirect business of a medium-sized or large-scale business that meets the criteria namely a) having net worth of more than Rp50.000.000 (fifty million rupiah) up to a maximum of Rp500.000.000 (five hundred million rupiah) excluding land and building of business premises; or b) has annual sales of more than Rp300.000.000 (three hundred million rupiahs) up to a maximum of Rp2.500.000.000 (two billion five hundred million rupiah). Third, medium-sized enterprises, which are stand-alone productive economic enterprises, carried out by individuals or business entities that are not subsidiaries or branches of a company owned, controlled, or become part directly or indirectly by small business or large business that fulfills criteria a) having a net worth of more than Rp500.000.000 (five hundred million copies) up to a maximum of Rp10.000.000.000 (ten billion rupiah) excluding land and building of business premises; or b) having annual sales of more than Rp2.500.000.000 (two billion five hundred million rupiah) up to a maximum of Rp50.000.000.000 (fifty billion rupiahs).

Based on the explanation of the criteria above UMKM can be concluded that the criteria classified in the category of micro, small and medium enterprises is based on net worth except land and building place of business and sales results for a year. Three important strategies have been worked out for empowerment, one is capacity building, second legislative and the third organizational strategies, which enable women to come out of their isolation, use their collective strength to gain control over self, economic and socio-political resources. One such outcome of these strategies is the formation of Self-Help Groups (SHGs) (Vinaygamoorthy et al, 2015)

\section{Method Results}

This research is a qualitative exploratory research. This study uses the Focus Group Discussion (FGD) method with the aim to build the same perception and objective equation in order to maintain SHG sustainability. FGDs are held by inviting a number of SMEs who are members of the SHG to be guided by a moderator. FGDs were conducted in January 2017. Subjects in this study were as many as 19 SMEs belonging to SHG in Surabaya with strong entrepreneurship capability. It is expected to be a provision to determine the strategy in dealing with ASEAN Economic Community (AEC). 


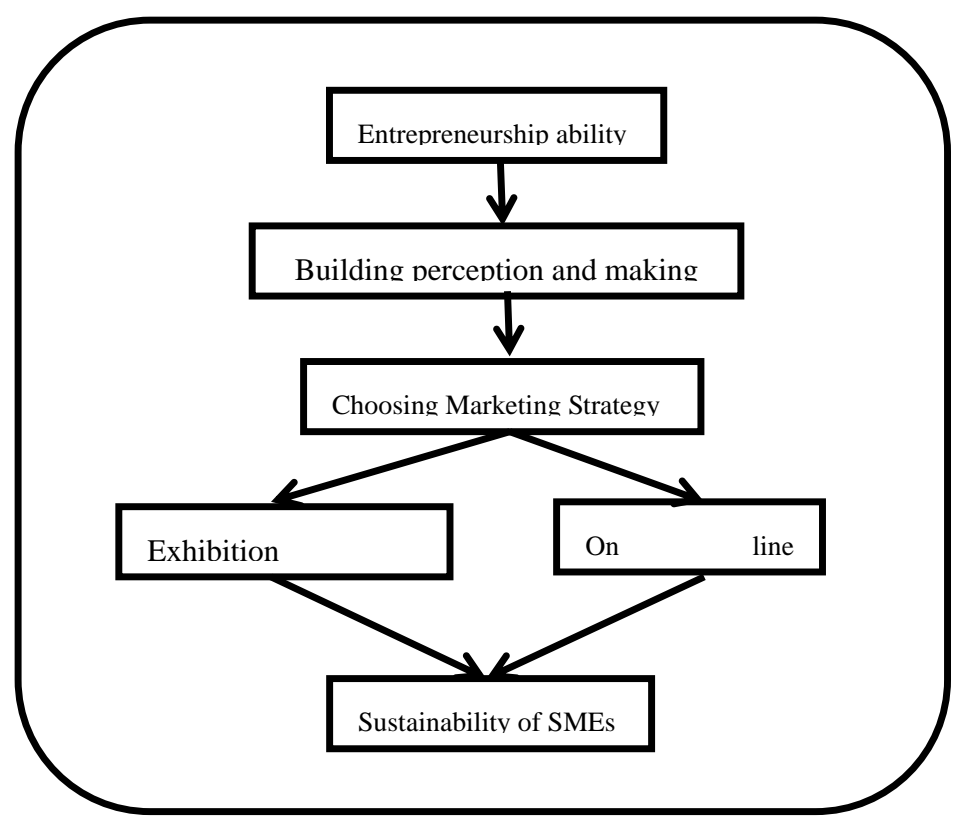

Figure 1. Theoretical framework

\section{Results}

The results of this study consist of several stages, namely the stage of establishing the perception equation among SHG members, determining the marketing strategy through exhibition, and determining the marketing strategy through online marketing.

\subsection{Building Perceptions and Goal of SHG}

Perception is fundamental in an activity. Perception will determine which direction an organization's container moves. Each member in the SMEs group incorporated in the SHG needs the same perception to determine the direction of their business development. Without such a common perception, SHG will not be able to thrive and be ready for liberal trade. Perceptions and goals here lead to the steps taken to prepare SHG for the free trade of the ASEAN Economic Community (AEC) era.

In developing the same perception and goals, 19 SHGs were invited to hold a gathering on Tuesday and Wednesday 17 and 18 January 2017 at STIESIA Surabaya campus Jl. Menur Prumpungan No.30. Surabaya. 19 SHG comes from various districts in Surabaya including District Benowo, district bubutan, district Bulak, and District Semampir Sawahan. In this FGD, the three researchers were moderators to condition and guide the discussion.

From the results of the FGD conducted some important problems related to the perception and objectives of SHG in facing free market competition in the era of ASEAN Economic Community (AEC), such as first importance of open-minded. Open-Minded is one way to open the perception and thinking to be open to all changes that occur in the environment. This attitude is required by members who are members of SHG to be ready in the face of market changes towards free trade. Second, mental readiness to face all the possibilities that will come. In addition to the thinking that must be open to change, mental readiness is also required. Free trade raises producers gathered from all directions and the free community chooses. This has consequences for local products competing with international products. This consequence must be balanced with mental readiness for all the possibilities that occur. Third, willingness to keep learning. The willingness to learn becomes an important point in an organization for those who want to move forward. If SHG wants to get ahead and be developed so that it is ready to face other producers, this attitude should not be forgotten. Willingness to continue learning will bring SHG to continue to evaluate their performance. So it will provide continuous improvement on SHG performance and earnings. Fourth, willingness to improve. Willingness to flourish goes hand in hand with the willingness to learn. The desire to develop as a major capital to change for the better in terms of SHG performance. Willingness to develop bring each individual who joined in SHG synergize and work together to achieve group goals.

Some of the above attitudes are the 4 main attitudes and priorities that each member must have with a strong 
commitment according to the FGD results. The commitment to run these four attitudes is a fundamental perception for SHG in the face of free trade to create SHGs that can survive in the face of change.

\subsection{Determining Marketing Strategy through Exhibition Participation}

After determining the equation of perception and SHG goals, the next step is the selection of marketing strategy. One of the chosen marketing strategy is to follow exhibition activities both in national and international level. Selection of this strategy is based on several things, including a) exhibition marketing strategy. The power of exhibition Marketing strategy can be done in several ways, one of them is by participating in exhibition both national and international. Selection of this strategy is not necessarily without reason. This strategy is chosen because the exhibition is a strategic step to introduce local products to foreign citizens. Foreigners who tend to be attracted to goods or handicrafts that are natural but can still enjoy in a comfortable atmosphere. Exhibition is considered able to attract the attention of the wider community from various circles. Targeting SHG product market is a special foreign community and the public in general; b) local wisdom value. The purpose of introducing SHG products through exhibition is to put forward on local wisdom. The value of a good is more valuable than cost sacrificed. The value of local wisdom is what SHG will focus on.

\subsection{Determining Marketing Strategy through Online Marketing}

In addition to marketing strategy in the form of participation in exhibition, another strategy chosen is through online marketing. It is undeniable that today's information technology greatly influences human behavior, including in the consumption behavior of goods and services. Selection of this strategy is based on some of the following benefits time efficienty, price transparency, and intention of purchasing. The online marketing system will shorten the time for consumers from the selection, decision-making, and purchase of products. Consumers no longer need much time to go to the store selecting goods and compare the product with others. Advantages like this are needed modern society. Behavior that promotes efficiency is one of the strategies to deal with free trade. Managing customers for the long term is much more necessary than getting a buyer only once. This can be achieved from the transparency of prices issued by manufacturers and their consistency. In the online marketing system transparency is very important. When the customer has trusted the product from the SHG store with the transparent price and commitment, the customer will be loyal to the product of SHG. Online marketing affects the intention of purchasing (Lim, et al, 2016). Intention purchasing is an important point in customer decision making. With the choice of the customer then the lift sales numbers increase. So that will eventually increase SHG revenue.

\section{Conclusion}

ASEAN Economic Community is a change of trading system towards a liberal direction that allows producers from all over ASEAN to enter and seek markets in other countries, including Indonesia. In order to face this group home industry incorporated in SHG must be able to compete with other manufacturers in national and international scale. Some of the strategies taken to improve SHG's performance are by participating in exhibition activities and implementing online marketing system. Participation in exhibition both national and international scale focuses on the protrusion of local wisdom value. This value is able to bring the attraction for the community both in the country and abroad. The selection of online marketing system brings several advantages such as time efficiency in selection, and product purchase. In addition, transparency which is the main focus seen by the customer can also be maintained.

\section{References}

A. B. R., Totok, S., \& Dody, S. (2012). Strategi Pemerintahan Desa dalam Meningkatkan Pendapatan Masyarakat Melalui Sektor Home Industry. Jurnal Ilmu Sosial, 1(1), 35-47.

Alma, B. (2000). Kewirausahaan. Alfabeta. Bandung.

Ardini, L., \& Respatia, W. (2011). Efektifitas Program Pelatihan Keterampilan Gakin Terhadap Tingkat pendapatan Gakin Kota Surabaya. Hibah Dosen Pemula Dibiayai oleh Kopertis Wilayah VII Kementerian Pendidikan Indonesia.

Berita Resmi Statistik. (2011, July). Profil Kemiskinan di Jawa Timur Maret 2011. BPS Provinsi Jawa Timur., No. 44/07/35Th.IX.

Das, S., Mitra, A., \& Md. H. Ali. (2015). A Study on the Impact of Women Self-help Groups (SHGs) on Rural Entrepreneurship Development-A Case Study in Selected Areas of West Bengal. International Journal of Scientific and Research Publications, 5(3).

Handayani, N., \& Ardini, L. (2016). Self-Help Groups Potential and Strategy in Increasing Local Product Quality 
Trough Sub-Contract Model to Maximize Income (Special Issue-1). International Journal of Management and Applied Science, 2(1).

Izedonmi, F., \& Okafor, C. (2007). Assessment of the Entrepreneurial Characteristics and Intentions among Academics.

Jahur, M.S., \& Quadir, S.M.N. (2012). Financial Distress in Small and Medium Enterprises (SMES) of Bangladesh: Determinants and Remedial Measures. Economia Seria Management, 15(1).

Lim, et al. (2016). Factors Influencing Online Shopping Behavior: The Mediating Role of Purchase Intention. Procedia Economics and Finance, 35, 401-410. https://doi.org/10.1016/S2212-5671(16)00050-2

Littunen, H. (2000). Entrepreneurship and the Characteristics of the Entrepreneurial Personality. International Journal of Entrepreneurial Behavior \& Research, 6(6), 295-310. https://doi.org/10.1108/13552550010362741

Lowden, J. S. (2007). Managerial Skills for the Entrepreneur. Emerald Backfiles.

Mangkuprawira, S., \& Hubeis, A. V. (2007). Manajemen Mutu SDM. PT Ghalia Indonesia. Indonesia.

Muljono, P. (2009). Upaya Pemberdayaan Masyarakat dan Pengentasan Kemiskinan melalui Model Posdaya (Pos Pemberdayaan Keluarga). Prosiding Seminar Hasil-hasil Penelitian IPB.

Mutaqin. (2010). Peran LPTK dalam Pengembangan Pendidikan Vokasi di Indonesia. Prosiding. Denpasar, 29 April-2 Mei 2010. Konvensi Nasional V APTEKINDO, FTK Universitas Pendidikan Ganesha.

Petty, \& Geoffrey. (2002). Creativity: Memaksimalkan Potensi Kreatif. Elex Media Komputindo. Jakarta.

Rejeki, D. P. S. (2006). Analisis Penanggulangan Kemiskinan Melalui Implementasi Program P2KM Di Kota Semarang. Thesis. Program Pascasarjana UNDIP. Semarang.

Siswoyo, B. B. (2009). Pengembangan Jiwa Kewirausahaan di Kalangan Dosen dan Mahasiswa. Jurnal Ekonomi, 2, 123-144.

Slamet, W., Bustaman, H., \& Soengkono. (2011, April) Model Pemberdayaan Ekonomi Wanita Nelayan Miskin Melalui Penerapan Teknologi Tepat Guna Terpadu. Majalah Ekonomi Tahun, XXI(1). Universitas Airlangga.

Suman, A. (2007). Pemberdayaan Wanita, Kredit Mikro, dan Kemiskinan: Sebuah Studi Empiris. Jurnal Manajemen dan Kewirausahaan, 9(1), 62-72.

Suryana. (2003). Kewirausahaan, Pedoman Praktis, Kiat dan Proses Menuju Sukses. Penerbit Salemba Empat. Jakarta.

Vinaygamoorthy, A., Saranya, B., \& Prema, G. (2008). Marketing Strategies and Financial Viability of Self Help Groups. A Study with special reference to Vellore District. Periyar University.

Yuwono, S., \& Partini. (2008). Pengaruh Peltaihan Kewirausahaan Terhadap Tumbuhnya Minat Berwirausaha. Jurnal Penelitian Humaniora, 9(2), 119-127. 